\title{
The politics of environmental justice: community development in Ecuadorian and Peruvian Amazonia
}

\author{
María Teresa Martínez and Eurig Scandrett
}

\section{Introduction}

This chapter addresses community development with indigenous communities in Ecuadorian and Peruvian Amazonia, whose territories have been the site of conflicts with the oil extraction industry. The argument developed in this chapter interconnects community development and environmental justice and is the result of a dialogue between the authors, based on case studies from the experience of one of us, Martínez, who worked between 2000 and 2009 as an activist, researcher and community worker with indigenous communities in the oil production areas of the Amazon. The indigenous peoples with whom Martínez conducted her work were the Cofán from Dureno, the Kichwa from Sarayaku,[[Please confirm correction]] both in Ecuador, and the Shipibo-Konibo from Canaán de Cachiyaku in Peru. The case studies include work with these groups as well as with employees of the oil companies and 'intermediaries' in the NGOs, the Church, activists and academics, including many adopting the role of community development practitioner, whether employed to do so or not.

Martínez describes the background to this work:

'My original intention was to bring indigenous voices to the forefront of academic debate: to expose the impacts of the unsustainable development promoted by the oil industry and to identify the strategies used by indigenous people to regain control of their own development. From the beginning I thought my main informants would be indigenous people with whom I had built relationships over the years through my work in Amazonian communities. 
However, people in all the oil-affected communities I worked with considered it necessary to include the points of view and strategies used by the 'powerful' oil companies as well as the indigenous people. Therefore, the decision of researching the 'powerful' in the oil conflict was taken in agreement with my informants. The ethical stance of the research remained politically committed to the interests of the indigenous 'survivor' communities.'

There is a lack of critical research about the powerful in society, and the need to 'study up' (Williams, 1989) has not been fully addressed. This is accentuated by the commodification of research and the barriers which powerful actors erect against researchers who are attempting to scrutinise the state and corporate power (Tombs and Whyte, 2002). The powerful are not exempt from public scrutiny. If they do not provide information when confronted with critical and independent research, they leave researchers with few options but to use deception and selective communication. Martínez explains:

\begin{abstract}
'When researching the 'powerful' and their activities in oil-affected areas, I felt at times as a spy, an unintended but necessary role to access information from the oil companies, an exhausting and stressful double-role. One coping mechanism was my work in the indigenous communities. The reason why I embarked on this research was because various communities and friends had asked me to. I had previous experience of working as a community worker and as an activist in oil-affected areas, and was in an ideal position to carry out this type of research. This required spending long periods of time in indigenous communities where I was given various community development roles, from leading workshops to designing project proposals and helping to organise cultural events. On other occasions I found myself in the middle of a protest or a violent situation, and needed to have a standpoint, as my role as an activist and international witness was required.'
\end{abstract}

In this context, the detached researcher has no place: on the contrary, community development, research and activism may go hand in hand and each can support the other. In that sense, the case material discussed here should be regarded as activist ethnography and action research undertaken by Martínez (Reason and Bradbury, 2006). This chapter 
constitutes a critical reflection on these experiences in dialogue with Scandrett.

We understand community development to be a process through which communities collectively mobilise to defend or enhance their means of livelihood and quality of life and a practice by key individuals who consciously facilitate this process, whether through community appointment, political commitment or professional employment. Theorists of community development have recognised the contradictions in its practice. Since the origins of community development in European colonialism and 'development' as a means of building the allegiance of post-independence populations, community workers have been located within communities that have been identified as 'problematic' by outsiders, and tasked with the contradictory role of supporting communities to identify and mobilise in support of their collective interests which may be opposed to the interests of the powerful (Mayo, 2008).

For the purpose of this chapter we have classified the actors in the relationship between community and the oil industry as the 'powerful', the 'survivors' and the 'intermediaries', all of whom have some locus in community work. The 'powerful' includes the state and foreign oil companies, state institutions, public relations (PR) companies, the military and foreign governments. The 'survivors' consist of indigenous people and their local, regional and national organisations. The 'intermediaries' include local, national and international NGOs and aid agencies, the Church, local councils, activists, academics and some governmental institutions that lead with indigenous issues. ${ }^{1}$ These categorisations are not intended to be analytical but rather heuristic and it is acknowledged that complex diversity exists within them. However, in interpreting the role which key agents play in the processes that are either explicitly named or may be understood as community development, this categorisation is helpful.

In a region where the presence of the state is minimal, the oil industry has become the main source for community development in indigenous communities through its 'Corporate Social Responsibility' (CSR) programmes in an effort to consolidate its presence in indigenous territory, what Collins (2006) has called 'dispossession through participation'. In many cases these industry-led attempts at community development are in conflict with communities' own development strategies and life projects. Some indigenous groups have evolved and transformed over the centuries into societies that represent a troublesome alternative to the current dominant neoliberal system based on concentration of power and accumulation of wealth. 


\section{Neoliberal states in Latin America: oil industry expansion and 'Corporate Social Responsibility'}

The national and transnational oil industry has been able to act with almost total impunity since the start of its operations in Latin America at the beginning of the last century (Kimerling and FCUNAE, 1993; Varea, 1995; Maldonado, 2001; Sawyer, 2004; Oilwatch, 2005; López, 2007). Four main interrelated factors favoured the unregulated growth of the industry: (1) the dire need of states for quick-fix and resourcebased solutions to the economic crises of their countries; (2) the shift in the 1980s from a corporatist to a neoliberal system imported from the US and other Western countries; (3) the lack of regulations on environmental and indigenous rights issues; and (4) expansion of the civilisatory mission of the evangelical group, Summer Institute of Linguistics (now SIL International). ${ }^{2}$

The Ecuadorian case is illustrative of an economy that suffered two major resource crises: the cacao crisis in the 1920s and the banana crisis in the 1960s. As Acosta (2003) points out, in the 1980s Ecuador 'changed from poverty-stricken banana grower to new-rich producer of oil':

Thanks to the oil bonanza, the GDP increased between 1972 and 1981 at an average annual rate of 8\% with spectacular rates in some years (more than 25.3\% in 1973), in particular for the industry, which increased by an average of $10 \%$ per year; while the product per person increased from $\$ 260$ in 1970 to $\$ 1,668$ in 1981 .

Although at the beginning of the 1970s the industry was under the control of the state, its remarkable profits in the following years attracted foreign investment. This, together with a favourable international climate for oil investments and the shift from a corporatist to a neoliberal ideology in the government, aided the entry into the country of transnational oil companies (Perreault, 2001; 2003: 66). Neoliberal regimes have also encouraged corporate-led globalisation by promoting free trade, privatisation and deregulation. Oil transnationals operating in Latin America did not have to worry, until recently, about complying with any environmental regulations or national and international laws regarding the individual and collective rights of indigenous people.

While the lengthy absence of environmental laws eased the uncontrolled development of the industry in indigenous territory, the lack of a regulated frame for consultation with and participation 
of the affected communities has become one of the main complaints of indigenous peoples and organisations (Melo, 2006: 19). The International Labour Organization (ILO) Convention 169 stipulates that indigenous peoples have the right to be consulted regarding any legislative or administrative measure that may affect them, oil developments included. However, in the case of resource exploration, the state is the owner of the subsoil. This means that indigenous peoples do not have integral ownership of their territory, since they own only what is on the surface. The fight for outright ownership of their lands has been the most contested issue during the 20 years of gestation of the United Nations Declaration on the Rights of Indigenous Peoples (UNDRIP). The declaration signals a great advance since it recognises the right of indigenous peoples to self-determination and free, prior and informed consent but it still does not give any veto control to the communities, a matter that is highly contested by governments.

Finally, another important factor for the entry of the oil industry into the Amazon was the previous arrival of the missionaries of the SIL, widely considered to have opened the doors to the extractive industries in the Amazon in the 1960s and 1970s by breaking the social cohesion of the indigenous communities and building airstrips that were later used by the oil companies (Stoll, 1983; Perkins, 2005: 141-3; Yashar, 2005: 146).

During the first years of the oil industry companies did not have to worry about the environmental and social impacts of their operations. Indigenous organisations were in their infancy, and most indigenous communities were unaware of the impacts that the industry might bring. Government planning was beginning to show recognition of environmental and indigenous rights, while social control in indigenous communities was assured by the presence of evangelical and Catholic missionaries. This does not mean that indigenous communities peacefully allowed the entry of the industry. Company representatives, especially those in charge of the seismic phase of the operations, were subject to attacks by various indigenous groups, but overall their paternalist strategy of petty gifts and short-term unskilled jobs for indigenous people kept the resistance at bay.

Although localised indigenous protests had been common since the colonial period, indigenous peoples started to influence national politics by forming or joining class-based organisations. The gradual departure from class ideals was partly due to the influence of the new indigenous intellectuals and the promotion of indigenous culture by the Catholic Church (León, as cited by Van Cott, 2005: 104). Amazonian organisations found it easier to organise around ethnic demands than 
Andean organisations. The social relations of production in much of the Andean region of many Latin American countries involved the hacienda system of contracted debt, in which Indian labourers (conciertos) were virtually owned by the hacienda owner. By contrast, in the Amazonian region the hacienda system had little impact. In addition, the remoteness of Amazonian communities, the bilingual education programmes promoted by missionaries versus the imposition of Spanish in public schools, and their special concept of territory contributed to the 'indianisation' of the movement. The main claim of Amazonian indigenous organisations was for indigenous territory, as the colonisation and extraction of natural resources promoted by both corporatist and neoliberal governments represented a direct threat to their collective subsistence. This constituted a marked difference from the concept of territory practised by Andean communities, where land was a social and economic production unit. The indigenous mobilisations in the 1990s consolidated the indigenous movements and made them visible and influential on a national and international scale.

The mobilisations carried out by the Amazonian indigenous movement during the last three decades have set an example of indigenous organising through non-violent actions and have marked the beginning of a new power relationship between the state and indigenous peoples whose demands could no longer be ignored. These mobilisations had an impact in the development of international law (ILO Convention 169 and the UNDRIP) and a whole range of international initiatives which have set up non-enforceable guidelines and principles for corporate responsibility, among them the United Nations Global Compact initiative and the Organisation for Economic Co-operation and Development (OECD) Guidelines for Multinational Enterprises.

These initiatives have considerably changed the pattern of relationship between the state, companies and communities. In order to operate in a friendly environment, companies in Latin America use community relations programmes (CRPs) as part of their CSR strategy. Parts of these agreements are compulsory for the companies by law, such as the compensation and reparation payments made for the use of the territory and for environmental contingencies. However, companies also see these programmes as voluntary 'good neighbours agreements' [[You have used the term 'good neighbourhood agreements' in the next subheading. Please correct if required]] that can be negotiated to minimise conflict.

CRPs are often the only community development strategies in these regions. Oil companies claim these programmes seek to mitigate the 
social impacts of oil extraction in the communities and to improve access to healthcare and education (Martínez, 2008). There are no binding international or national standards on how these programmes should be implemented (Varea, 1995; Wray, 2000; Narváez, 2004; Shamir, 2004). A common characteristic of all the programmes analysed in these case studies is that they have become a tool for the oil companies to access indigenous communities, promoting division and dependency on the company.

\section{Visions of development}

\section{Community development led by the 'powerful': good neighbourhood agreements, [[See previous query]] PR strategy and the absence of the state}

Wray (2000: 56-60), who carried out fieldwork in the Ecuadorian Amazon and examined the complex relations between the state, the companies and indigenous peoples, explains that the agreements reached during negotiation of a CRP vary depending on three factors: the phase of the oil operation, the level of international awareness about the specific project, and the strength of the indigenous organisation. We would add other factors: the PR strategy used by the company and the state to promote oil activities; the environmental and social record of the company; the size of the company; and whether it is national or transnational. During the seismic phase of the operations the agreement between the companies and the communities tends to be short term, since the company cannot assure the discovery of oil reserves, and if the finding is not economically viable it will cease operations in the area. In the exploration phase the agreements are long term, as this minimises conflict, and companies fund whole projects instead of specific demands. The first contact with the communities normally takes place through the environmental impact assessment (EIA) or, more recently, through the consultation process. Some indigenous organisations complain that companies use the EIA to access the communities and start negotiations and the CRPs to secure their permanence in the communities.

What has happened in practice is illustrated by the case of the indigenous community of Sarayaku in Ecuador and the Argentinean oil company CGC. Although consultation had not taken place, CGC contracted the PR company Daimi Service to help them sign an agreement with the communities of the oil block and start seismic 
operations in Sarayaku territory. In an interview a representative at Daimi explained:

'This case was especially challenging for us, so I decided to invest my own money and told the company [CGC] that if I did not manage to sign agreements with all the communities in the oil block they would not have to pay me. They had tried before with other consultants and they achieved nothing, but we managed to sign a contract with 26 of the 28 communities' (David Luján, 15 March 2007).

Luján stated that the practices of his company are based on high levels of transparency, taking into account the perspectives of all the actors and working with the local authorities. This claim contrasts with interviews carried out with indigenous leaders from different areas in Ecuador who accused Daimi of favouring the interests of the oil companies, blackmailing leaders and working under cover.

CGC used an aggressive PR strategy in the Pastaza region because it met with strong resistance in the Sarayaku community. The Sarayaku fought back and organised the Kapari (meaning 'shout') campaign to create awareness of the conflict, which was supported internationally. The Sarayaku are an exceptional case, in which a single and isolated community has managed to resist what seemed inevitable, the exploitation of oil in its territory. However, the price paid for this resistance has been high, as the community has lived in a state of alertness and psychological pressure for the last decade, and the damage caused to the social network by the interruption of their cultural traditions, the animosity created with neighbouring communities and the violation of sacred places by CGC will be very difficult to repair.

Many of the oil contracts in the Amazon area were signed 30 years ago, when there was no need for consultation or CRPs. Although consultation rights and environmental regulations are not retroactive, communities that were never compensated for the use of their territory are now starting to claim compensation, as in the dispute between the Shipibo-Konibo people of Canaán in Peru and the Maple company. After various direct actions that brought the conflict to the national level, the community managed to sign a compensation agreement with the company and a long-term CRP. An indigenous leader of the local organisation FECONBU reflects on the struggle of the people of the community of Canaán for compensation and the direct actions - 'fight actions' in his words - that they took: 
'Before the fight actions we got only palliatives from the company ... then we carried out three fight actions and we waited a long time for the company ... We proposed that the company should pay us five million soles [approximately 1.6 million dollars] for the use of our territory over the years ... What we have got is 152,000 soles per year [approximately 49,800 dollars] and a community relations programme, but we still do not see results ... The company thought we were asking for too much because they value the territory in a very different way ... but this payment is just for the use of our land, no environmental or health impact assessment of our population has been done yet ... as a federation we all agreed that we are against oil exploitation in our lands ... We have a new company coming, Amerada Hess, they want to exploit oil in all the river basin, but we all agreed to say no ... Now the problem is ... when other communities see that here in Canaán we have got compensation, they may think this is easy to get, they may think oil companies are good for our development, but then what is going to be left for us in the future?' (Arturo Valiente, interview, 17 October 2006).

Valiente's commentary stresses the importance of CRPs as a negotiating tool for both sides, but it also shows that they can be a double-edged sword. On the one hand communities that have not received any sort of compensation from the oil companies for decades are right to demand compensation which takes into consideration the value that indigenous peoples attach to their land. This is often a complex matter, since many of the affected areas have an unmeasurable value for the people. However, if a price for compensation is to be set, the calculations cannot be based only on the price per hectare set by the national government. On the other hand, the prospect of compensation and a long-term CRP can lead the community to engage in a development process over which they do not have control.

For many communities the CRP negotiated with the company, before or after oil exploitation, is the only external support they get, and for them it becomes a matter of survival and an opportunity for development. Many communities see transnational companies as institutions with endless funds which take out all the resources of the country without leaving real benefits for the people; their demands may therefore range from capacity-building training to the construction of a school or a road. Negotiation between an oil transnational and an 
indigenous community is an uneven process, in which communities often do not have access to the information and legal advice necessary for fair negotiation. Even in the ideal case that a fair process is established, once the company takes on the role of the state a clientelist relationship is created, which is difficult to break.

The case of the state oil company and medium-size companies varies slightly, since they normally do not have the same economic resources to negotiate the CRPs as an oil transnational. The PR strategy of the national oil companies is also less aggressive, although practices such as militarisation of the oilfields and the cooption of indigenous leaders are common.

Companies are aware that they are replacing the state and that they should not be the ones in charge of the development of indigenous communities; however, most of the oil company CEOs and representatives interviewed for this research blame the state for its inability to institutionalise the extraction of resources in the Amazon region, its absence from the negotiation with communities, and the lack of investment in the communities in which oil is extracted.

Although state health and education programmes do not reach many indigenous communities, state presence is not entirely lacking in the Amazon region. For more than two decades, especially since the arrival of the oil industry, the region has gradually developed its administrative structures, and decentralised state institutions are present in every Amazonian province. National representatives of the state may not participate in the negotiations between the companies and the communities, but a multi-stakeholder local or regional board could be created to monitor the transparency and accountability of the oil operations and to decide the best way to distribute the percentage of the oil rent that by law goes to the local and regional governments. Although state institutions in the Amazon region are under-resourced they can still play an important role in institutionalising oil operations in the region.

The state and oil companies, as powerful actors in the oil conflict, are both responsible for this chaotic scenario. The absence of the state in some oil regions of Southern countries does not justify the methods employed by the oil companies to counter resistance and to negotiate with indigenous communities. Among these methods are divisionism, bribery, cooption, psychological pressure, militarisation and legal threats.

In both Ecuador and Peru the principal indigenous organisations and their non-indigenous allies have adopted a clear position against the extractive industries in indigenous territory or have demanded a 
moratorium on all oil activities until better conditions for indigenous peoples can be guaranteed, but there are other indigenous organisations and voices which see in dialogue and negotiation with the industry the only means of assuring their development and they struggle to achieve a fair negotiation in which respect for indigenous culture is the main priority. The debate around the oil industry is polarised in these two countries. Indigenous peoples may differ in their understanding of how oil-rich territories should be managed and what are the possible alternatives to oil exploitation; however, they converge on vital issues such as the need to preserve their territory, culture and sovereignty. It is on constant dialogue and shared views that their future hangs.

\section{Community development led by the 'survivors': education, cosmovision and political participation}

Education seems to be vital for the cultural survival of all indigenous peoples. In those communities whose way of life has been affected by the oil industry, the realisation that education is a long-term survival mechanism is now internalised and has become a priority of development programmes led by the communities themselves.

In order to better respond to external threats such as the oil industry, indigenous people have identified various forms of education and training required. They have also stressed the need for an intercultural model of education which would depart from previous assimilatory policies and would focus instead on identity and diversity. Education of indigenous peoples is a political question, a right in itself linked to the right to self-determination. In Latin America national programmes on Intercultural Bilingual Education (IBE) were started a few decades ago with high expectations had by indigenous organisations that sought the decolonisation of indigenous peoples' education.

It is beyond the scope of this chapter to get into the details of IBE and what it has meant politically for indigenous peoples. However, the main failure of these programmes in Ecuador and Peru has been the control that these states and international institutions have exerted over them, leading to the imposition of the dominant culture and language in indigenous and rural areas, to the detriment of cultural diversity. The effects of this kind of education were described by a Cofán woman:

'The western system doesn't respect the ways we think and live, especially through education. That's the biggest threat to indigenous peoples because it's a silent weapon, much more dangerous even than the oil industry because it 
colonises the hearts and minds of young people, of children, devaluing, and bit by bit it has the effect that the people, the system of [indigenous] peoples, the ancestral structure, becomes lost. That's the big threat' (Marta Flores, interview, 12 February 2007).

Some oil-affected communities have decided to take more responsibility for their own education instead of waiting for reforms to materialise. Changes in the school curriculum introduced by the community include the participation of the elders to teach indigenous cosmovision, increasing the time the children spend in nature or in collective communitarian activities, and rescuing the use of the traditional costume instead of expensive state uniforms. These decisions are taken in the general assembly of the community. Meso-American cosmovision is a structured and systemic world view and related belief system that integrates the structure of space and rhythms of time into a unified whole and influences all the aspects of life.

Sarayaku, for example, has received external support to create its own programme for IBE teachers, counting on the help of foreign volunteer teachers who rotate every three months. The training provided in Sarayaku complies with the dispositions of the regional and national IBE programmes, but the community proposes the most relevant topics for the curriculum. For example, 'globalisation and the age of information technology' has become an important subject for the community as they are aware that part of their success against CGC is due to the use of media such as the Internet, radio and filming.

Indigenous people are also aware that education is not limited to the formal sector or the IBE programmes. There are other crucial educational routes if communities want to influence policies and secure representation at various levels of the decision-making process. One of these is the role of the community as cradle for the formation of leaders who may later work for the local and regional federations. Traditionally leaders have worked on a voluntary basis, their election a duty and an honour that could only be avoided with strong justification. Today, leaders from local federations may be paid if the organisation receives funds from NGOs or other institutions. Community members sometimes see leaders as more interested in the salaries offered for these positions than in representing their people. Although envy and mistrust will always exist, leaders and members of communities struggling against the oil industry have worked tirelessly as advocates of indigenous peoples' rights, and some have risked their lives. The oil conflict has brought the leadership of the movement closer to the grassroots and has 
also served as a springboard to the regional and national levels for those leaders who have been involved in local struggles. The conflict with the oil industry has also created the need to train the youth in rights and advocacy issues, as they will be the future leaders and responsible for organising resistance and developing strategies for survival. The training in advocacy and indigenous and territorial rights has gone hand in hand with community development activities around the revalorisation of traditional culture and the creation of spaces in which the elders and the youth can converge.

A leader of the Cofán community of Dureno explains:

'Latterly the whole Cofán people has been worried because the last shamans are now dying, and then what's going to happen? The problem has been lack of confidence, because preparing to be a shaman takes a long time and is difficult. The shamans don't think the young people are interested, and at the same time the young people believe that the shamans don't want to teach them. Also, since the oil companies' arrival the sacred plants have been more difficult to find, and the young people go off to the towns and no longer have time for these teachings ... here an association of young people, AJONCE, has been formed with a double aim, on the one hand that they should know their rights and the threats that the oil industry holds over us, and on the other, to rescue our cosmovision' (Ernesto Segundo, interview, 11 February 2007).

During the past five years [[For clarity, I suggest you substitute 'Since [year], ...' for 'During the past five years']] the community of Dureno has been approached on several occasions by national and foreign oil companies, and AJONCE has had an important role in maintaining the position of the community against oil operations in their territory. AJONCE has received a small amount of funding from Friends of the Earth, but has now managed to become sustainable through a traditional fish farm project and a programme of national and foreign volunteers. Recently AJONCE members built a house of yajé (a sacred plant of shamanism) as a centre for learning shamanism and other traditional teachings, but the location of the house at the top of a hill is strategic, as stated by one of the young members:

'We decided to build the yajé house on the hill because it's a secluded and pleasant place, good for learning shamanism 
... but also we were worried by several bids to carry out mining on that hill ... now, with the yajé house there, that area can't be used for mining' (Carlos Flores, interview, 14 January 2007).

\section{Community development led by the 'intermediaries'}

The 'intermediaries' also play an important role in the development of oil-affected communities. The roles of intermediary actors are diverse: they may act as supporters of indigenous movements, mediators in the oil conflict, funders of community development projects in oilaffected communities or researchers of the oil conflict. Indigenous peoples and communities coordinate or seek the support of these 'intermediaries' for different purposes, and the participation of the latter in their development can be short term, long term or intermittent. International environmental NGOs such as Amazon Watch, Rainforest Information Network, Oilwatch and their local counterparts are most likely to support indigenous peoples by organising a campaign against a particular oil company and providing information to the communities about the impacts of the industry and their collective rights. Other NGOs such as Oxfam support indigenous communities in such areas as governance and education; Oxfam has been active in evaluating how the ILO Convention 169 principle of prior and informed consent has been implemented in oil-affected communities. Intermediary actors such as political ecologists and the NGOs Acción Ecológica and Friends of the Earth have also helped in unmasking oppression by corporations and states and in recompensing indigenous peoples for past and current environmental and social injustices.

Through such collaboration indigenous peoples and the 'intermediaries' nurture each other and solidarity links are created. Indigenous peoples gain technical and moral support, while NGOs gain the grassroots support of an important actor for their wider agenda against the expansion of extractive industries. However, NGOs and indigenous organisations have admitted in interviews that although they may have a common agenda they still need to work on issues such as representation, capacity building and ownership and that collaboration between them is still a learning process. It seems that there is a new tendency among indigenous organisations to become more selective of the number and quality of the community development projects that they decide to move forward, prioritising the real needs 
of the community or organisation, its ability to manage funds and its participation in all stages of the project.

Academics, activists, the Ombudsman Office and the Catholic Church have also had an important role as mediators, advisers and human rights monitors in the oil conflict in recent years. Some of them become prominent as designers of campaigns against the oil industry and community development strategies. At the beginning of the oil industry in the Amazon region, the evangelical organisation SIL, the military and the Catholic Church were the only institutions in the area, and the Church therefore played a prominent role in community development and in opposing the abuses committed by the state and the military at that time. The Church continues to have a strong influence on state officials and society and often uses this power to raise the demands of indigenous peoples. However, the flood of NGOs that has arrived in Amazonia and the increasing involvement of advocacy NGOs in the oil conflict has led to friction with the Church, which is especially critical of the threat to indigenous peoples.

\section{Looking for justice and redress: from environmental justice to ecological debt}

The role of a community worker in these contexts is determined by whose interests they are employed to serve. The biggest employers of community workers are the oil corporations whose purpose is to obtain community consent for oil exploration and extraction and to promote a development model compatible with capitalist industry. While indigenous communities have obtained some concessions from negotiating with the powerful companies, including community development goals, this has inevitably been at the expense of loss of their land and environmental resources as well as cultural and spiritual erosion through the imposition of capitalist relations of production. As has been recognised elsewhere, community development is here a tool of neoliberalism, of achieving consent for the dispossession of resources in the interests of corporate capital. Where the state is absent or weak it is unable or unwilling to provide for alternative community development strategies. 'Intermediaries' who engage in community development are faced with the contradiction of falling into line with corporate dispossession or else helping to mobilise against it, in many cases relying on the mixed blessings of international solidarity. 
Some networks of NGOs, indigenous organisations and academics have developed discourses that help locate the struggles of communities in wider geopolitical and historical processes, such as environmental justice and ecological debt.

Environmental justice theories challenge dominant views of development by emphasising that the current model is built at the expense of unfair access to the earth's resources and distribution of environmental impacts. Martínez-Alier (2002: 13-14) argues that the environmentalism of the poor, or environmental justice movements constitute a social response to an economic logic based on values incommensurable with those of communities. Community development processes in which the commercial valuation of a community's resources is non-negotiable are flawed from the start. In such processes, alternative values based on indigenous cosmovision are tolerated only so long as they do not impede dispossession. However, environmental justice struggles emerge as part of a rejection of the imposed commercialisation of resources that are culturally valued in non-financial terms. Assessing and analysing the proposed engagement with oil companies' CRPs and financial compensation packages requires a process involving critical community development. It means learning about structures of commercialisation on a scale that is largely alien to indigenous communities, articulating and asserting what is important in indigenous cultures and involving the wider community in negotiation, discernment and mobilising support. There is a strong interrelationship between environmental justice struggles and critical community development processes, whether facilitated by indigenous leaders or outsiders from 'intermediate' groups (Scandrett, 2000).

While principles of environmental justice focus on equity, ecological debt focuses on moral and economic redress. Ecological debt is an economic concept that exposes the legacy of the unfair distribution of resources and the subsequent conflicts this may bring. Neoclassical economics can only make sense of resource depletion, environmental damage, species extinctions or biodiversity loss by attaching a price to the intact resources in order to measure against the marginal price of development which accompanies the damage. However, this consistently undervalues the resources of communities whose poverty, political marginalisation or non-monetised social relations deny them market leverage. As a result, the value in market terms of the legacy of destruction and resource depletion under colonial and post-colonial exploitation is considerable, and far outweighs the financial debt of the countries' governments accumulated through borrowing. Thus, the former colonised countries of the Global South are ecological 
creditors to varying degrees, while the 'developed' countries owe an ecological debt to the rest of the world.

First, ... the exports of raw materials and other products from relatively poor countries are sold at prices which do not include compensation for local or global externalities. Second, rich countries make a disproportionate use of environmental space or services without payment, and even without recognition of other people's entitlements to such services (Martínez-Alier, 2002: 213).

The Oilwatch network describes various principles which show how the oil industry creates ecological debt: from how oil export prices do not include the costs related to the externalities they produce, to the contribution of the industry to climate change and the extermination of indigenous cultures (Oilwatch International, 2000). Ecological debt does not imply a precise calculation to measure the financial compensation required for repayment - this would be almost impossible to measure and require buying in to the neoclassical logic that ecological models of economics seek to critique. However, as a political and moral tool, the ecological debt concept demonstrates the intrinsic relationship between the exploitation of the resources of the Global South and the wealth of the Global North. The dispossessed indigenous communities of Amazonian Ecuador and Peru are therefore ecological creditors morally, if not legally entitled to recompense. And for community development workers in the Global North, indebted status shifts the terms of engagement with communities in impoverished communities at home. Community development that incorporates an understanding of ecological debt leads to potentially radically new strategies of addressing issues such as housing, fuel poverty, land use planning, antipollution campaigns and resource exploitation at home.

The model of environmental justice requires indigenous and outsider community workers to support mobilisation against the oil corporations and their agents, including those who implement CRP. Ecological debt, moreover, is a tool which has been used by community workers across the world to generate international solidarity among all those who are dispossessed by the economic logic of neoliberalism.

\section{Notes}

1 In the research study, all representatives of the oil industry requested anonymity. Permission was granted by most 'intermediaries' and 'survivors' to use their names. 
Nonetheless, pseudonyms have been used throughout the chapter to protect participants' identities.

2 SIL International (current name of the former Summer Institute of Linguistics) started in 1934 to train missionaries in basic linguistic, anthropological and translation principles. The group has been denounced for using a scientific name to conceal its religious and capitalist agenda (Bonner, 1999: 20). SIL has been expelled from Brazil, Ecuador, Mexico and Panama, and restricted in Colombia and Peru (Cleary and Steigenga, 2004: 36).

\section{References}

Acosta, A. (2003) 'Desde abajo: "Texaco en el banquillo de los acusados", Diario Hoy, 4 June, 15.

Bonner, A. (1999) We will not be stopped: Evangelical persecution, Catholicism, and Zapatismo in Chiapas, Mexico, [[Please insert place of publication]]: Universal Publishers.

Cleary, E.L. and Steigenga, T.L. (2004) 'Resurgent voices: Indians, politics, and religion in Latin America', in E.L. Cleary and T.J. Steigenga (eds), Resurgent voices in Latin America: Indigenous peoples, political mobilization, and religious change, New Brunswick, NJ: Rutgers University Press, 1-24.

Collins, C. (2006) 'People and place: the Royal Bank of Scotland and "Community Engagement", Concept, 16(2): 9-16.

Kimerling, J. and FCUNAE (1993) Crudo Amazónico, Quito: Abya Yala. López, M.D. (2007) Pueblos sin derechos: La responsabilidad de repsol en la Amazonía Peruana, Peru: Intermón-Oxfam.

Maldonado, A. (2001) La manera occidental de extraer petroïleo, Quito: Oilwatch.

Martínez, M.T. (2008) 'Building bridges: participatory and emancipatory methodologies with indigenous communities affected by the oil industry', Enquire, 1(1): 1-17.

Martínez-Alier, J. (2002) Environmentalism of the poor: A study of ecological conflicts and valuation, Cheltenham: Edward Elgar.

Mayo, M. (2008) 'Community development, contestations, continuities and change', in G. Craig, K. Popple and M. Shaw (eds) Community development in theory and practice, Nottingham: Spokesman, 13-27.

Melo, M. (ed) (2006) Consulta previa: Ambiente y pétroleo en la Amazonía Ecuatoriana, Quito: CDES. 
Narváez, I. (2004) 'Metodologías de relacionamiento comunitario no ortodoxas: análisis político para abordarlas', in G. Fontaine (ed), Petróleo y desarollo sostenible: Las apuestas, Quito: FLACSO, 75-90.

Oilwatch (2005) 'A civilization based on oil', Resistance Bulletin, 56, http://redamazon.files.wordpress.com/2007/11/oil-basedcivilizationbol.pdf.

Oilwatch International (2000), Oil and ecological debt, www. cosmovisiones.com/DeudaEcologica/a_oilwatch2.html.[[URL is not active. Please provide alternative]]

Perkins, J. (2005) Confessions of an economic hit man, London: Ebury Press.

Perreault, T. (2001) 'Developing identities: indigenous mobilization, rural livelihoods, and resource access in Ecuadorian Amazonia', Cultural Geographies, 8(4), 381-413.

Perreault, T. (2003) 'Changing places: transnational networks, ethnic politics, and community development in the Ecuadorian Amazon', Political Geography, 22: 61-88.

Reason, P. and Bradbury, H. (2006) 'Introduction: inquiry and participation in search of a world worthy of human aspiration' in $\mathrm{P}$. Reason and H. Bradbury (eds) Handbook of action research, London: Sage, $1-14$.

Sawyer, S. (2004) Crude chronicles: Indigenous politics, multinational oil, and neoliberalism in Ecuador, Durham, NC: Duke University Press.

Scandrett E. (2000) 'Community work, sustainable development and environmental justice', Scottish Journal of Community Work and Development, 6: 7-13

Shamir, R. (2004) 'The de-radicalization of corporate social responsibility', Critical Sociology, 30: 669-89.

Stoll, D. (1983) Fishers of men or founders of empire? The Wycliffe Bible translators in Latin America. A US evangelical mission in the third world, London: Zed Books.

Tombs, S. and Whyte, D. (2002) 'Unmasking the crimes of the powerful', Critical Criminology, 11, 217-36.

Van Cott, D.L. (2005) From movements to parties in Latin America: The evolution of ethnic politics, New York, NY: Cambridge University Press.

Varea, A.M. (ed) (1995) Marea negra en la Amazonía: Conflictos ambientales vinculados a la actividad petrolera en el Ecuador, Quito: Abya Yala.

Williams, K. (1989) 'Researching the powerful: problems and possibilities of social research', Crime, Law and Social Change, 13(4): 253-74.

Wray, N. (2000) Pueblos lidígenas Amazónicos y actividad petrolera en el Ecuador: Conflictos, estrategias e impactos, Quito: Ibis Dinamarca. 
Yashar, D.J. (2005) Contesting citizenship in Latin America. The rise of indigenous movements and the postliberal challenge, Cambridge: Cambridge University Press. 